\title{
Reasons of drug use among adolescents: implications for clinical nursing care
}

\author{
Motivações do consumo de drogas entre adolescentes: \\ implicações para o cuidado clínico de enfermagem \\ Motivaciones de la adición a las drogas entre adolescentes: \\ implicaciones para el cuidado clínico de enfermería
}

How to cite this article:

Soares FRR, Oliveira DIC, Torres JDM, Pessoa VLMP, Guimarães JMX, Ana Monteiro ARM. Reasons of drug use among adolescents: implications for clinical nursing care. Rev Esc Enferm USP. 2020;54:e03566. doi: https://doi.org/10.1590/S1980-220X2018058003566

Francisco Rafael Ribeiro Soares ${ }^{1}$

Deceles Ingrid de Carvalho

Oliveira $^{2}$

\section{Joana Darc Martins Torres ${ }^{3}$ \\ Vera Lúcia Mendes de Paula \\ Pessoa $^{3}$}

José Maria Ximenes Guimarães ${ }^{3}$

Ana Ruth Macêdo Monteiro ${ }^{3}$

${ }^{1}$ Universidade do Estado do Rio Grande Norte, Faculdade de Enfermagem, Mossoró, RN, Brazil.

${ }^{2}$ Universidade do Estado do Rio Grande Norte,

Faculdade de Educação, Mossoró, RN, Brazil.

${ }^{3}$ Universidade Estadual do Ceará, Centro

de Ciências da Saúde, Programa de

Pós-Graduação Cuidados Clínicos em

Enfermagem e Saúde, Fortaleza, CE, Brazil.

\section{ABSTRACT}

This is a theoretical essay which aims to reflect on the reasons for and why adolescents use drugs and their implications for clinical nursing care. It used the referential of social phenomenology of Alfred Schutz. The main reasons identified were: to attenuate existential crisis, form social bonds and to have fun. The reasons for this are related to the characteristics of adolescence, a breakdown in social and family ties and the conditions of programmatic vulnerability. Motivations provide important information for developing person-centered, not drug-abuse-centered care strategies. Nurses' caregiving action is based on emancipatory health education strategies grounded on the strategy of reducing harm and risks related to drug use and the possibility to help adolescents become aware of their biographical situation in a face-to-face relationship, so that they can (in knowing yourself) act to promote their health.

\section{DESCRIPTORS}

Adolescent; Substance-Related Disorders; Nursing Care; Harm Reduction; Health Education; Public Health Nursing. 


\section{INTRODUCTION}

The use of substances which promote alterations in consciousness, named herein as drugs, has been present in the most diverse societies since the earliest times as a structuring historical condition, the result of a cultural production with variable meanings, being used in religious, devotional, therapeutic, even festive and recreational rituals, taking root in ethnic and national cultures ${ }^{(1)}$.

There was never a single behavior of drug consumption and its use in different civilizations was not linked to meanings of dependence ${ }^{(2)}$. Consumption patterns followed the principle of moderation, avoiding the extremes of both abstinence and overuse. This cultural, ethnic, religious, and national consumer perspective continued throughout history until the mid-eighteenth century when the popular use of exciting substances spread with the advent of the industrial revolution to aid the working class in labor performance on strenuous journeys. The modus operandi of drug production, trade, and consumption from then on began to have new governability centered on the relationship with commodification. The passage between the $19^{\text {th }}$ and $20^{\text {th }}$ centuries marks the moment when this phenomenon is assimilated as a social problem ${ }^{(3-4)}$.

This new consumption pattern, which had lost the temperance principle, led to the development of private and governmental initiatives to control discipline in the means of production and ensure maximum laboriousness. As a result, measures were taken to crack down on the use of various drugs, especially in the United States, which were later spread around the world in a "drug war" and "zero tolerance" strategy which emerged from a prohibitionist consensus and became a tactic of global geopolitical domination ${ }^{(5)}$.

In the contemporary consumerist and individualist mode of relationship, in which the subject is recognized for what they have or can consume, a particular phase of life becomes particularly susceptible to unmoderated drug use because of its peculiar characteristics: adolescence ${ }^{(6)}$.

This stage is considered very significant and determinant in an individual's development due to the biological, psychological and social relation changes which are established ${ }^{(7)}$. It is understood as a transitional period in which an individual's capabilities are developed from discoveries and choices which directly impact on the future. This phase is also characterized by the existence of risk behaviors, impulsive acts and decreased inhibitory control of the subject in confronting their experiences ${ }^{(8)}$. Drug use among adolescents entails greater risks because they are more vulnerable to their effects, including from the point of view of neurological development of the prefrontal cortex ${ }^{(9-11)}$.

The health sector, especially nursing, plays an important role in the processes of protection and promotion of the well-being of adolescents, seeking strategies based on a humanistic perspective, understanding their life contexts and the motivations for drug use $\mathrm{e}^{(3,12)}$.

Given this scenario, this essay aims to reflect on the reasons for and why adolescents use drugs and their implications for clinical nursing care.
This theoretical essay is the result of reflections emanating from the discipline Fundamentals and Practices of Clinical Nursing and Health Care offered in the Graduate Program of Clinical Care in Nursing and Health of the Universidade Estadual do Ceará (PPCCLIS/UECE), and is based on Alfred Schutz's Social Phenomenology, specifically on the theoretical conception of the reasons for and why.

According to the author ${ }^{(13)}$, the actions of subjects are behaviors which are produced and interpreted from their existential motives. The reasons for or the reasons so that are understood as a "state of affairs, the end, according to which the action was carried out"(13). In contrast, there are the reasons why, which refer to their body of knowledge, past experiences in the biopsychosocial sphere and which determine how the subject acts.

Reflexive analysis was based on a broad and comprehensive study of the literature with study/analysis objects being adolescents and their relationship with drug use and abuse. Books and reports from specialized study and research centers in Brazil were initially read, such as the Center for Drug Abuse Studies and Therapy $(C E T A D / B A)$ and the Brazilian Center for Information on Psychotropic Drugs (CEBRID).

$A$ vast search was then performed from this basis in national and international databases (VHL, SciELO, LILACS, PubMed Central, Cochrane) and Google Scholar, without time limit, using descriptors (Alcoholism, Smoking, Illicit Drugs, Substance-Related Disorders, Adolescent, etc.) and keywords associated with the topic (Drug Abuse, Drugs, Adolescents, Youth, Drug Use, etc.), using them alone or in combination with the Boolean term AND. All materials related to the object of this reflection were read in order to identify the various reasons for drug use among adolescents indicated by the studies, which were then analyzed and categorized from the perspective of Alfred Schutz's social phenomenology ${ }^{(13)}$.

\section{REASONS FOR}

The reflective analysis of the literature enabled us to point out three major categories of motivation for which relate to achieving objectives: attenuating an existential crisis, forming social bonds and fun.

\section{Attenuating AN eXISTENTIAL CRISIS}

Reflections on the meaning of life emerge in adolescence as the individual matures, thus not meaning something pathological, but representing an essentially human characteristic. It is in this concern for the meaning of life that the person expresses what is most human in themself, sometimes developing some suffering in these discoveries ${ }^{(14)}$ which mainly result from failures: in incorporating new life issues, in acquiring new knowledge and in behavior change, which are essential tools for healthy transitions.

These transitional processes are complex and unique, with diverse patterns which demand recognition of their own characteristics and social environment, as expressed in Afaf Meleis' Theory of Transitions. In this theoretical model, the transition consists of a passage of a stable place or 
condition to another, requiring an aggregation of knowledge, behavioral changes and defining of the self ${ }^{(15)}$.

In the case of adolescence, several critical events ranging from the very particular aspects of individual vulnerability of this phase of life to problems related to drug use require attention, knowledge and experience from nurses, as this transition increases weaknesses of adolescents in performing self-care and care. Nursing interventions are needed at this critical juncture in the universal, selective, and indicated prevention of primary to tertiary levels, as well as health promotion ${ }^{(15-16)}$.

In this sense, drug use fulfills a subjective and social need which each one has in their particular experience of 'being'. In this context, its consumption acts almost as an antidote which enables adolescents to get rid of this existential crisis, even leading them to escape, if only momentarily, the choices and responsibilities that the arrival of maturity puts before them. Teenagers use drugs as an escape valve for the problems generated by a culture in crisis which engender anxiety, fear, insertion difficulties and low resilience ${ }^{(17)}$.

\section{FORMING SOCIAL BONDS}

Another important reason concerns the need felt by young people to relate, form new social and affective bonds, be a part of peer groups and have visibility in them ${ }^{(18)}$.

Drug use, licit or illicit, gives adolescents the status of being fearless, uninhibited and a sense of power. The constitution of these relations is part of the very formation of the personality of being. The space of social bonds is fundamental in developing the adolescent's identity. The social perspectives of young people become impoverished due to the invisibility to which they are subjected: the school moves away and does not seek to understand their context; health services do not welcome them and they are often judged rather than provided care; the work is disqualified and undervalued, and all this obscures hopes for a better future ${ }^{(8)}$.

\section{Fun}

As the last reason for, there are the possibilities of fun that drug use presents. The pursuit of leisure is not an exclusive condition of adolescence, but there are diminished inhibitory aspects in it which provide experiences that would seem unthinkable at other stages of life $\mathrm{e}^{(10)}$.

Pleasure and fun are routinely cited by young people as goals for using marijuana, alcohol and other drugs ${ }^{(6)}$. The search for adrenaline and satisfaction is also mentioned ${ }^{(8)}$. This use is usually associated with the gathering of friends, parties and sexual encounters, and this relationship portrays the drug as something which somehow leads to delight.

\section{REASONS WHY}

Three categories of reasons why also emerged: the characteristics of adolescence, a breakdown in social and family ties, and the conditions of programmatic vulnerability.

\section{Characteristics OF ADOlescencE}

Adolescence makes a real cut in the reality of life of these subjects, taking them from the tranquility of childhood and putting them into a limbo of acceptance, which requires adult responsibilities, but without the autonomy to do so ${ }^{(18)}$.

Internal conflicts coupled with this rupture in realities and clashes with the family and society generate stresses which sometimes demand escape from these movements ${ }^{(18)}$. Studies conducted since the 1970 s point to a number of essential risk factors for drug use in adolescents, indicating a correlation of a depressive personality structure with affective immaturity and identity problems associated with young people who become addicted to some drug ${ }^{(19)}$.

Another important factor regarding drug use commonly employed by young people concerns impulsiveness and curiosity. This condition of searching for new life experiences and new knowledge for one's personal collection is natural to man, who wants these experiences to project their future actions ${ }^{(14)}$.

It is urgent to recognize these characteristics in order to produce singular care for these subjects, since the precocious use of drugs is associated with problems in the intellectual, psychological, emotional and social development of adolescents in several studies ${ }^{(11)}$.

\section{BREAKDOWN IN SOCIAL AND FAMILY TIES}

Several family and social situations or experiences are described as risk factors for drug use among adolescents. Most focus on two aspects: affective distancing from parents and drug use by parents and friends.

The affective distancing of parents includes a series of conjunctures, such as the fragile bond between mother and child, the absence of one spouse in raising and educating children, the use of domestic violence, lack of affection, support and/or family connection in solving the problems of the young people, greater permissiveness towards degrading actions, etc. ${ }^{(6,11)}$.

Another risk factor is drug use by parents or friends. The onset of use in adolescence usually occurs by domestic stimulation. Alcoholic beverages and tobacco reach young people through a close friend, with the vast majority occurring via family and friends. Children of parents who have problems related to drug abuse usually have similar problems ${ }^{(6)}$. There is a strong association between cigarette smoking by the father and an addiction then being developed by the adolescent ${ }^{(20)}$. Although alcohol and cigarette (tobacco) use usually start at home, it is with friends that young people drink more often, in more quantity, and in more unhealthy situations ${ }^{(6)}$.

\section{Programmatic Vulnerabilitity CONDitions}

The existence of a complex network of social, economic, structural, environmental, emotional and psychological factors which influence the full exercise of citizenship by adolescents is well known.

Vulnerability refers to a state in which individuals or groups have reduced self-determination for various reasons, and are unable to guarantee self-protection of their interests, health and development. There are three components which are closely intertwined with situations of vulnerability: the 
individual, the social or collective and the programmatic or institutional ${ }^{(21)}$.

The individual dimension of vulnerability concerns the specific aspects of adolescents' way of life, their behaviors, attitudes, biological aspects, etc. The social or collective dimension relates to the cultural, social and economic contexts which determine opportunities for access to information, goods and services. The programmatic or institutional represents the difficulties imposed in the scope of services, policies, in the definition of focuses and priorities, in the financing, both by the public and private initiative and civil society agencies ${ }^{(22)}$.

In the object of this essay, the first two dimensions had some aspects analyzed in the categories of reasons for already discussed. Regarding the institutional dimension, it is observed that adolescents at this stage have greater difficulty in accessing health services, education and social assistance which give them conditions to live properly with drug use. Vulnerability in these individuals is related to characteristics which hinder the development of adaptive responses to crisis situations when they occur ${ }^{(17)}$.

In this structural dimension, the vulnerability of adolescents already starts in formulating some guiding policies of the healthcare network and in planning programs and actions. However, there are also failures in their implementation and effectiveness as well as in their supervision, such as non-compliance with the law by establishments which sell alcohol and tobacco to children and adolescents. It is also perceived a critique on the care systems (SUS and SUAS) with their complex network of services involving public, private and philanthropic institutions, which are not necessarily in harmony ${ }^{(23)}$.

The social spaces in which they operate lack specific leisure, sports and culture places for this public, offering alternatives to productively occupy their time ${ }^{(24)}$. Poor income distribution and the consequent lack of access to social goods determine the living conditions of these young people, making them vulnerable to drugs in their three dimensions.

\section{IMPLICATIONS IN CLINICAL NURSING CARE OF THE REASONS FOR AND WHY}

Clinical nursing care can be defined as an "(...) act of caring with responsibility, ethics and social commitment provided by qualified nursing professionals through technical-scientific knowledge and clinical eyes, using attentive listening, touch, speech, in order to meet the real needs of the individual being cared for, with respect to their uniqueness, life history and individuality"(25).

The production and provision of this care to adolescents who use drugs or who are at high risk of doing so demands a welcoming attitude from nurses, without prejudice or moralism, which shows the young person that there is space for dialogue and for building a face-to-face relationship. There needs to be professional understanding that drug use, whether legal or illegal, is not an abnormality or anomaly, but rather a human cultural condition influenced by a number of factors, and that the subject being cared for has a number of reasons related to both past experiences and future goals.
Understanding the set of ideas, values and beliefs of the subjects is essential for understanding the meanings which support their actions in the world of life ${ }^{(13)}$. To this end, nurses need to know the reasons for and why of drug-using adolescents, who provide important information for the development of person-centered rather than drug-abused care strategies. It is not up to the nurse to demand abstinence from anyone, nor can they decide which are the best attitudes to be taken.

Thus, clinical nursing care for this public should focus on strategies for mental health promotion, prevention and therapeutic interventions which favor the necessary conditions for the adolescent to be able to fully understand their reasons and determinations in order to develop necessary conditions to promote their autonomy and take constructive steps in their life. These actions should not be random or extracted only from the nurse's own repertoire, but should be based on the best national and international scientific evidence and on national mental health policy focusing on subject autonomy and harm reduction.

Regarding mental health promotion, clinical nursing care should focus on actions which provide the best conditions within the available environment and context so that adolescents develop their mental health to the point of seeking to adopt a lifestyle with healthier behaviors. Some nursing theories support this clinical care, such as those of: interpersonal relationships, health promotion model, transitions and adaptation model ${ }^{(26)}$.

It is possible to observe some important intersections in these theoretical models for nursing work, such as the dynamics of the care process, the importance of the nurse-adolescent relationship and the autonomy of the subject in seeking to promote their own health, with it being up to the professional to recognize the biopsychosocial characteristics of the individual, their environment and their culture in order to use the tools in the face-to-face relationship to pursue a change in healthy behavior ${ }^{(26)}$.

Regarding primary prevention, the clinical care of nurses should be guided by a search for empowering adolescents, aiming to help them make decisions freely and enlightened, fostering "a strengthening of autonomy and individual responsibility in relation to misusing drugs" ${ }^{(27)}$. Health education strategies should be structured leading to solid individual reflections which enable them to deal with the whole reality and context of substance use and abuse ${ }^{(28)}$.

In this sense, it is appropriate to use diversified tools to develop strategies in the territory and using spaces (such as the school and the basic health unit) based on harm reduction. In this intersectoral relationship, the Health at School Program can be an important locus for nurses to prevent and promote mental health.

Every individual has a unique biographical situation and therefore adolescents' knowledge is influenced, and their actions will be experienced according to the meaning they attribute to them ${ }^{(13)}$.

The practice of nurses in secondary prevention is based on risk and harm reduction. Professionals should recognize individual possibilities of non-use, delayed use and 
risk reduction as possibilities for their actions ${ }^{(27)}$. As clinical nursing care demands scientific knowledge, preventive guidance should be anchored in respectable information. Police conduct which is not consistent with the caregiving function should be avoided ${ }^{(29)}$.

An important tool, especially in primary healthcare, is the brief, concise, short-term therapeutic technique which helps subjects understand the risks and harms caused by drug use, motivates them to reduce, modify or discontinue use, and gives them the autonomy to set objective goals and a 'menu of options' on how to achieve them ${ }^{(30)}$.

The nurse must act more to help the adolescent regain ownership and authority over their own history than to intervene in their life world. They should act in a positive and collaborative, health-oriented way. It is essential for professionals and adolescents to be willing to maintain a face-to-face relationship in which both are aware of each other and focused in the same space and time towards convergent goals ${ }^{(13)}$.

\section{FINAL CONSIDERATIONS}

Adolescence is a phase of life which represents a transition and a breakdown at the same time, and directly influences the development of the subject in their biological, psychological, emotional and social aspects. Impulsive, curious, status-seeking attitudes are common characteristics in this period. Drug use among young people constitutes an important space for nurses to act in producing their clinical care.

Knowing the reasons for and why these subjects use drugs is a prerequisite for performing a person-centered rather than substance-based work, helping them to identify the difficulties which exist in their biographical situation and to promote coping strategies to recover the ability to live with their social condition.

The main reasons identified in the literature were: to attenuate existential crisis, form social bonds and fun. The reasons for this are related to the characteristics of adolescence itself, the breakdown in social and family ties and programmatic vulnerability conditions. Thus, it is assumed that care production which does not take these reasons into consideration is at risk of being inefficient.

In relation to each other, both the adolescent and the nurse use their knowledge in daily life, and all the experiences already lived influence their meeting face-to-face with each other.

Therefore, nurses' caregiving action is grounded on emancipatory health education strategies and based on reducing harm and risks related to drug use and on the possibility of helping adolescents in a face-to-face relationship to become aware of their biographical situation, so that they can knowingly act to promote their own health.

\section{RESUMO}

Trata-se de um ensaio teórico que objetiva refletir sobre os motivos para e por que dos adolescentes usarem drogas e suas implicações no cuidado clínico de enfermagem. Utilizou-se do referencial da fenomenologia social de Alfred Schutz. Os principais motivos para identificados foram: a atenuação da crise existencial, a formação de vínculos sociais e a diversão. Já os motivos por que estão relacionados às características próprias da adolescência, às rupturas dos laços sociais e familiares e às condições de vulnerabilidade programática. As motivações fornecem importantes informações para o desenvolvimento de estratégias de atenção centralizada na pessoa e não na droga de abuso. A ação cuidadora do enfermeiro se consolida a partir de estratégias de educação em saúde emancipatórias e pautadas na estratégia da redução de danos e riscos relacionados ao consumo de drogas e na possibilidade de, em uma relação face a face, ajudar o adolescente a tomar ciência de sua situação biográfica, para que possa, conhecedor de si, agir com vistas à promoção de sua saúde.

\section{DESCRITORES}

Adolescente; Transtornos Relacionados ao Uso de Substâncias; Cuidados de Enfermagem; Redução do Dano; Educação em Saúde; Enfermagem em Saúde Pública.

\section{RESUMEN}

Se trata de un ensayo teórico que objetiva reflexionar acerca de los motivos para y por qué de la adicción de los adolescentes a las drogas y sus implicaciones en el cuidado clínico de enfermería. Se utilizó el marco de referencia de la fenomenología social de Alfred Schütz. Las principales motivaciones para identificadas fueron: la atenuación de la crisis existencial, la formación de vínculos sociales y la diversión. Ya las motivaciones por qué están relacionadas con las características propias de la adolescencia, las rupturas de los lazos sociales y familiares y las condiciones de vulnerabilidad programática. Las motivaciones proporcionan importantes informaciones para el desarrollo de estrategias de atención centralizada en la persona y no en la drogadicción. La acción cuidadora del enfermero se consolida mediante las estrategias de educación sanitaria emancipadoras y basadas en la estrategia de la reducción de daños y riesgos relacionados con la adicción a las drogas y la posibilidad de, en una relación cara a cara, ayudar al adolescente a tomar consciencia de su situación biográfica, a fin de que pueda, conocedor de sí, actuar con vistas a la promoción de su salud.

\section{DESCRIPTORES}

Adolescente; Trastornos Relacionados con Sustancias; Atención de Enfermería; Reducción del Daño; Educación en Salud; Enfermería en Salud Pública.

\section{REFERENCES}

1. Marinho LCP, Carmo DRP, Souto VT, Pelzer MT, Costa RF. Body, drug and movement. REME Rev Min Enferm. 2016;20:e987. DOI: http:// www.dx.doi.org/10.5935/1415-2762.20160057

2. Boarini ML. Drogas na adolescência: desafios à saúde e à educação. Psicol Pesq. 2018;12(2):57-67. DOI: https://doi. org/10.24879/2018001200200175

3. Rosa PO. Drogas e a governabilidade neoliberal: uma genealogia da redução de danos. Florianópolis: Insular; 2014.

4. Lacerda CB, Fuentes-Rojas M. Significados e sentidos atribuídos ao Centro de Atenção Psicossocial Álcool e outras Drogas (CAPS AD) por seus usuários: um estudo de caso. Interface (Botucatu). 2017;21(61):363-72. DOI: http://dx.doi.org/10.1590/1807-57622016.0060 
5. Csete J, Kamarulzaman A, Kazatchkine M, Altice F, Balicki M, Buxton J, et al. Public health and international drug policy. Lancet. 2016;387(10026):1427-80. DOI: https://doi.org/10.1016/S0140-6736(16)00619-X

6. Willhelm AR, Cabral JCC, Steiger JO, Silva JFF, Ugarte LM, Almeida RMM. Consumo de álcool na adolescência e relação com uso excessivo de bebidas alcóolicas dos pais: estudantes de quatro escolas de Porto Alegre. Psico (Porto Alegre). 2015;46(2):208-16. DOI: http://dx.doi. org/10.15448/1980-8623.2015.2.18129

7. Moura NA, Monteiro ARM, Freitas RJM. Adolescents using (il)licit drugs and acts of violence. Rev enferm UFPE on line [Internet]. 2016 [cited 2018 Sept 05];10(5):1685-93. Available from: https://periodicos.ufpe.br/revistas/revistaenfermagem/article/download/13543/16314

8. Hale DR, Viner RM. The correlates and course of multiple health risk behaviour in adolescence. BMC Public Health. 2016;16:458. DOI: https://doi.org/10.1186/s12889-016-3120-z

9. Spear LP. Consequences of adolescent use of alcohol and other drugs: studies using rodent models. Neurosci Biobehav Rev. 2016;70:22843. DOI: https://doi.org/10.1016/j.neubiorev.2016.07.026

10. Silveri MM, Dager AD, Cohen-Gilbert JE, Sneider JT. Neurobiological signatures associated with alcohol and drug use in the human adolescent brain. Neurosci Biobehav Rev. 2016;70:244-59. DOI: https://doi.org/10.1016/j.neubiorev.2016.06.042

11. Cerutti F, Ramos SP, Argimon IIL. A implicação das atitudes parentais no uso de drogas na adolescência. Acta Colomb Psicol. 2015;18(2):17381. DOI: http://dx.doi.org/10.14718/ACP.2015.18.2.15

12. Oliveira AJ. Disparity in the conceptions of psychoactive substance addiction treatment: reflexes and implications among professionals, models and institutions present in the care services. SMAD Rev Eletr Saúde Mental Álcool Drogas. 2017;13(2):93-100. DOI: https://doi. org/10.11606/issn.1806-6976.v13i2p93-100

13. Schutz, A. Sobre fenomenologia e relações sociais. Petrópolis: Vozes; 2012.

14. Fiedler MW, Araújo A, Souza MCC. The prevention of teenage pregnancy in adolescent's view. Texto Contexto Enferm. 2015;24(1):30-7. DOI: http://dx.doi.org/10.1590/0104-07072015000130014

15. Guimarães MSF, Santos IMM, Silva LJ, Christoffel MM, Silva LR. Parenthood of parents of newborns hospitalized due to congenital syphilis in the light of the transition theory. Texto Contexto Enferm. 2018;27(4):e1190017. DOI: http://dx.doi.org/10.1590/0104-07072018001190017

16. Lima CFM, Santos JLG, Magalhães ALP, Caldas CP, Erdmann AL, Santos I. Integrating transitions theory and grounded theory for nursing research and care. Rev Enferm UERJ. 2016;24(5):e19870. DOI: https://doi.org/10.12957/reuerj.2016.19870

17. Bittencourt ALP, França LG, Goldim JR. Vulnerable adolescence: bio-psychosocial factors related to drug use. Rev Bioética. 2015;23(2):3119. DOI: http://dx.doi.org/10.1590/1983-80422015232070

18. Nery Filho A, MacRae E, Tavares LA. As drogas na contemporaneidade: perspectivas clínicas e culturais. Salvador: EDUFBA/SciELO; 2012.

19. Costa GG. Fatores essenciais de risco de uso de drogas por adolescentes: utilizando modelagem de equações estruturais. Rev Ciênc Human. 2016;50(1):209-40. DOI: https://doi.org/10.5007/2178-4582.2016v50n1p212

20. Ferreira MMSRS, Torgal MCLFPR. Tobacco and alcohol consumptiom among adolescents. Rev Latino Am Enfermagem. 2010;128(2):122-9. DOI: http://dx.doi.org/10.1590/S0104-11692010000200017

21. Rodrigues NO, Neri AL. Vulnerabilidade social, individual e programática em idosos da comunidade: dados do estudo FIBRA, Campinas, SP, Brasil. Ciênc Saúde Coletiva. 2012;17(8):2129-39. DOI: http://dx.doi.org/10.1590/S1413-81232012000800023

22. Ribeiro KCS, Pereira LB, Wiese IRB, Silva J, Saldanha AAW. Consumo de álcool e tabaco e associação com outras vulnerabilidades em jovens. Psicol Saúde Doenças. 2017;18(2):348-59. DOI: http://dx.doi.org/10.15309/17psd180206

23. Nóbrega VM, Reichert APS, Viera CS, Collet N. Longitudinalidade e continuidade do cuidado à criança e ao adolescente com doença crônica. Esc Anna Nery Rev Enferm. 2015;19(4):656-63. DOI: http://dx.doi.org/10.5935/1414-8145.20150088

24. Zappe JG, Dell'Aglio DD. Risco e proteção no desenvolvimento de adolescentes que vivem em diferentes contextos: família e institucionalização. Rev Colomb Psicol. 2016;25(2):289-305. DOI: http://dx.doi.org/10.15446/rcp.v25n2.51256

25. Moreira PV, Monteiro ARM, Silva LMS, Rodrigues DP, organizadoras. O cuidado clínico de enfermagem. Fortaleza: EdUECE; 2015.

26. Bittencourt MN, Marques MID, Barroso TMMDA. Contributions of nursing theories in the practice of the mental health promotion. Referência. 2018;4(18):125-32. DOI: https://doi.org/10.12707/RIV18015

27. Brasil. Lei n. 11.343, de 23 de agosto de 2006. Institui o Sistema Nacional de Políticas Públicas sobre Drogas - SISNAD; prescreve medidas para prevenção do uso indevido, atenção e reinserção social de usuários e dependentes de drogas; estabelece normas para repressão à produção não autorizada e ao tráfico ilícito de drogas; define crimes e dá outras providências [Internet]. Brasília; 2006 [citado 2018 jul. 15]. Disponível em: http://www.planalto.gov.br/ccivil_03/_ato2004-2006/2006/lei/111343.htm

28. Schneider JA, Limberger J, Andretta I. Habilidades sociais e drogas: revisão sistemática da produção científica nacional e internacional. Av Psicol Latinoam. 2016;34(2):339-50. DOI: https://doi.org/10.12804/apl34.2.2016.08

29. Gomes TB, Vecchia MD. Harm reduction strategies regarding the misuse of alcohol and other drugs: a review of the literature. Ciênc Saúde Coletiva. 2018;23(7):2327-38. DOI: http://dx.doi.org/10.1590/1413-81232018237.21152016

30. Abreu AMM, Parreira PMSD, Souza MHN, Barroso TMMDA. Profile of consumption of psychoactive substances and its relationship to sociodemographic characteristics: a contribution to a brief intervention in primary health care, Rio de Janeiro, Brazil. Texto Contexto Enferm. 2016;25(4):e1450015. DOI: http://dx.doi.org/10.1590/0104-07072016001450015 